\title{
The Study of Service Quality and Competitiveness of Secondary Education in West Sumbawa
}

\author{
Sukardi, L. A. Wardana \\ The Faculty of Teacher Training and Education, University of Mataram, Indonesia \\ kardi_unram@yahoo.co.id
}

\begin{abstract}
Determine: the quality of education services and the level of competitiveness of the education on high school level (SMA) in West Sumbawa Regency. This study uses a service quality method involving 210 high school of stakeholders as subjects which were determined by random sampling. The instrument was adapted from an instrument developed by Amin (2011), which includes eight national educational standards of Indonesia (content, graduation, learning, assessment, educators and staff, facilities, management, and financing standard) and four factors of competitiveness (input factors, demand conditions, the relevance of education, and education strategy). Data were Analyzed using Importance Performance Analysis (Martilla \& James (1977) and analysis of Diamond Porter (1990). The survey found that the expected content standards, processes, financing, management, facilities and infrastructure, and competency standards are not in line the reality so that it becomes priority for the improvement. While the result of the survey indicates a low capacities for the four competitiveness factors; input, demand, the relevance of education, and education strategy.
\end{abstract}

Keywords - service quality, competitiveness, education

\section{INTRODUCTION}

Almost every country or institution has its own construction-related quality of service (including the quality of education). The quality of service according to Deming as cited in Dursun et al. (2014) is related to customer satisfaction with the products/services of the company. Much earlier, Parasuraman et al. (1985) restricts the quality of service associated with the perception gap between the expectations of the services rendered institutions. In other thoughts, Parasuraman et al. (1991) provide 10 attributes of service quality, namely: reliability, responsiveness, competence, accessibility, courtesy, communication, credibility, security, empathy, and tangibles. In the context of education, it is definitely reflected by the difference between expectations with reality, so Sallis (1993) mentions quality is fitness purpose. Study of Seng and Ling (2013) gave the attributes of quality educational services, such as: instructors, learning resources, academic courses, assessment, student engagement, students' satisfaction.

In Indonesia, the education service quality attributes is constructed in the form of National Education Standards (NES), which includes: Standard of contents, learning, competence of graduates, management, teachers and educational administrators, facilities and infrastructure, financing, and evaluation. However, service quality of educational institutions, especially secondary education (high school) by $8 \mathrm{NES}$ is still assumed to show a poor performance. Empirical evidence based on the results of study conducted locally in Indonesia found that most of SMA students do not yet understand fully the 8 NES as well as their accomplishment (Wildan et al., 2011) and out of the $8 \mathrm{NES}$, only competency standards that can be regarded to achieve a pretty good performance as indicated in the National Examination (Muchlis et al., 2011). In the context of learning, the quality of service is influenced by inputs (instrumental input) and the learning process which still nuance teacher centered and does not encourage creative thinking, contextual learning as well as underdevelopment of life skill development programs.

Under these conditions, it is assumed that the level of competitiveness of the graduates of high school level is also low. In fact, Porter (1990) asserted that the competitiveness of graduates can reveal the progress of a country. Some conditions that reflect weak competitiveness of high school graduates, among others: (1) the high percentage of unemployment of the high school graduates. The Indonesian Central Statistics Agency (BPS), for example, recorded a record $10.17 \%$ of $32,395,801$ of the high school graduates are unemployed; (2) not all high school graduates can go on to Higher Education (PT). It is recorded that the School Participation Rate (APS) on Higher Education level in Indonesia is $20.14 \%$. While in the province of Nusa Tenggara Barat (NTB) where this study took place, the School Participation Rate is only $22.64 \%$. This means that there are more than $77 \%$ of high school graduates who fail to pursue higher education (PT); and (3) the emergence of other social issues as the impact of the above problems, namely: social conflict, Drugs, and others. These conditions directly impact on the weakening of the social, economic, ineffective and inefficient use of educational resource, and the declining of public respect and trust in the secondary education.

Thus, in order to accelerate the improvement of service quality and competitiveness of high school graduates, it is necessary to map out the current condition of education which is then compared to the expectations of society through empirical study. Therefore, this study was aimed to: (1) determine the condition of the quality of educational services of the high school level of based on 8 
NES; and (2) determine the level of competitiveness of senior high school graduates.

\section{METHODS}

\section{A. Sampling}

This study uses ServQual (service quality) developed by Parasuraman et.al. (1994) by comparing the difference between perception and expectation of the quality of educational services. The survey was conducted in West Sumbawa regency (KSB) Indonesia, involving 210 senior high school education stakeholders as respondents. Overall, respondents are determined by cluster random sampling. First, the determination of sample schools is based on the representation that represents the potential of local advantages of every district in KSB. Second, the selection of the respondents in each school is conducted randomly, especially for teachers, students, parents, business / working world, parents, non-governmental organizations in education, and board of education. All school principals in the area automatically becomes respondent.

\section{B. Research Instruments}

Aspects of the quality of educational services is measured by the accomplishment of 8 NES adapted from the Instrument developed by Amin (2011) and aspects of competitiveness measured by the four competitiveness factors according to Porter (1990).

\section{1) National Education Standards}

Eight NES captured using interviews and questionnaires in the form of a Likert scale with 5 options, both for aspects of expectation and perception/reality $(1=$ bad to $5=$ very good $)$. Aspects of content standards consisting of 6 items (e.g. statement: "schools develop local curriculum by involving stakeholders education"); 6 items for learning process standard (for example "preparation of lesson plans are already developed based on the principles of active participation of students"); 10 items for competency standards (e.g., "students engage in learning activities related to the analysis and solution of complex problems"); 12 items for educators standard (e.g., "teachers teach the topic which is relevant to their educational background"); 7 items for infrastructure and facility standard(e.g., "the school has good infrastructure/facilities for teaching and learning"); 13 items for management standard (e.g., "school has formulated and set the vision, mission, and purpose"); 10 items for financing standard (e.g. "schools have annual records including infrastructure and asset value document"); and 8 items for assessment standards (e.g. "teachers use the results of assessment for learning improvement").

\section{2) Competitiveness of Education Factor}

The four competitiveness factors of education are obtained by using interviews and questionnaires in the form of a Likert scale with 5 options, both for aspects of expectation and perception/reality $(1=$ bad to $5=$ very good). Input factor has 5 item statement (e.g., "school is tailored to local potential '); 6 items for demand conditions (for example "market demand for graduates of the school"); 6 items for the relevance of educational (e.g. " the curricula conform the need of industrial world in the are "); and 3 items for education strategies (e.g. "the developed competency supports the development of the local sector").

\section{3) Analysis Techniques}

Techniques of analysis use descriptive statistics, comparative analysis, and analysis of the suitability of the perception wih the expectation by using the quadrant Importance Performance Analysis developed by Martilla and James (1977). Decision-making is based on the results of the analysis: (1) the first quadrant (Concentrate these); (2) quadrant II (Keep up with the good work); (2) Quadrant III (Low Priority); and (3) Quadrant IV (Possibly Overkill). While for the Competitiveness factors, the suitability of Diamond Porter (1990) is used.

\section{FINDINGS}

\section{A. Findings Validity and Reliability}

Based on the value of the alpha test, as shown in Table 1 , it can be seen that there is internal consistency and reliability for all items. The test results using Cronbach's $\alpha$ for all aspects of the NES and competitiveness factor has exceeded the threshold value of 0.70 as recommended by Nunnally (1978). Thus, a high score of Cronbach's $\alpha$ indicates the fulfillment of internal validity and reliability for all the items in every aspect of NES and competitiveness factors studied. In addition, all items being studied demonstrated high reliability and internal consistency.

TABLE I. FINDINGS OF RELIABILITY STATISTICS OF EDUCATION SERVICES QUALITY

\begin{tabular}{|c|c|c|c|}
\hline NES Components & Expectation & & Perceptions \\
\hline Content Standard & .727 & Cronbach $\alpha$ & .847 \\
\hline Proccess Standard & .749 & & .844 \\
\hline $\begin{array}{l}\text { Output competence } \\
\text { standard }\end{array}$ & .864 & & .887 \\
\hline $\begin{array}{l}\text { Teachers and } \\
\text { educational } \\
\text { administrators } \\
\text { standard }\end{array}$ & .758 & & .881 \\
\hline $\begin{array}{l}\text { Infrastructure and } \\
\text { facility standard }\end{array}$ & .785 & & .853 \\
\hline $\begin{array}{l}\text { Management } \\
\text { standard }\end{array}$ & .816 & & .901 \\
\hline Financing Standard & .814 & & .892 \\
\hline Evaluation Standard & .794 & & .866 \\
\hline
\end{tabular}

TABLE II. FINDINGS OF RELIABILITY STATISTICS OF COMPETITIVENESS FACTORS

\begin{tabular}{lc}
\hline Competititveness factors & Cronbach $\alpha$ \\
\hline Input factors & .765 \\
Demand factors & .878 \\
Relevance of education to Industrial world & .799 \\
Education Strategy & .723 \\
\hline
\end{tabular}




\section{B. Conditions of Service Quality Education Level High School}

Results of the study found that the overall achievement of quality services can be divided into four parts in accordance with the quadrant division based on analysis of the suitability of Importance Performance Analysis (Martilla \& James, 1977) as visualized in Table 3 and Figure 1.

TABLE III. ACHIEVING QuALITY OF SERVICE LEVEL High SCHOOL

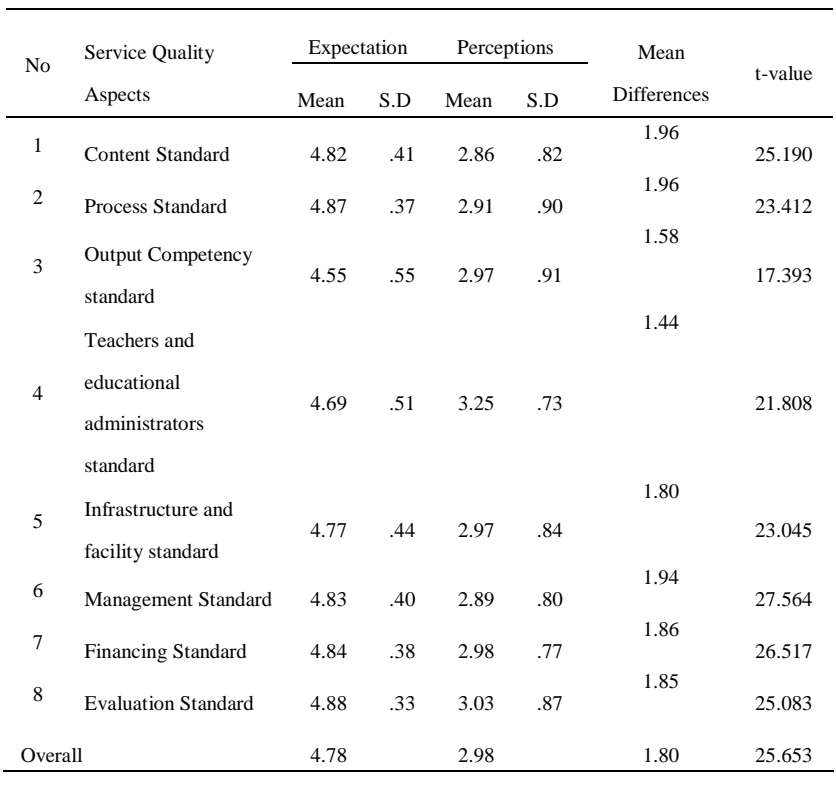

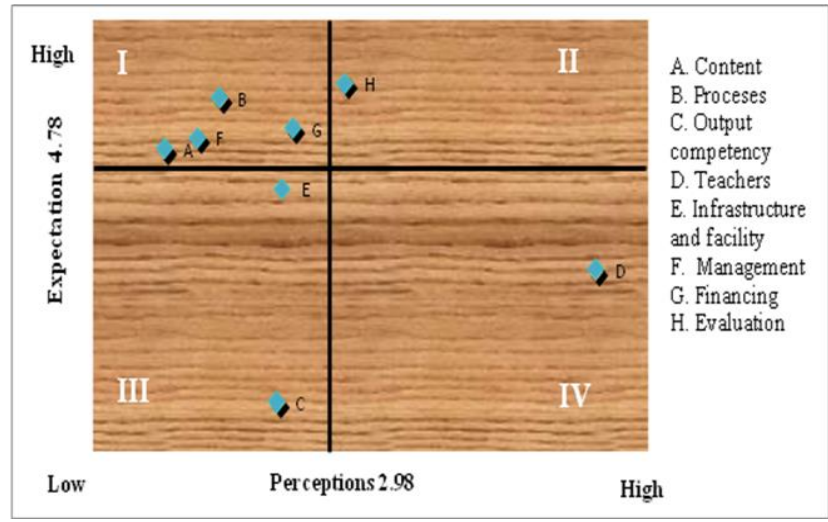

Fig. 1. Quadrant of Educational quality Services at High School in West Sumbawa, Indonesia

Based on Table 3 and Figure 1, it can be explained that: First, quadrant I; the components that go in this quadrant are content standards, process standards, management standards, and financing standards. All components included in this quadrant are considered important but showed a poor performance. Therefore, the school and other stakeholders need to work harder to perform better in this quadrant. Secondly, quadrant II; Component that falls into this quadrant is a standard assessment. This standard is also considered important and has shown a good performance. Third, quadrant III; component that goes in this quadrant is infrastructure and competency standards. All that go in this quadrant are considered less important and relatively perform less. As this components in this quadrant do not optimally perform, it should be considered a crucial issue and be placed at the second priority to be upgraded after quadrant I. Therefore, schools and other interested parties also need to provide energy and mobilize all resources to meet all the standards that go in this quadrant. Fourth, Quadrant IV; components that go in this quadrant is the standard of teachers and educational administrators. Components that go in this quadrant are considered less important and public's expectation to the accomplishment of this component is relatively low. The inclusion of these standards in quadrant IV is due to the number of teachers in KSB is sufficient, so the emphasis is only on teacher distribution at schools in some regions. Therefore, school authorities and relevant institutions have to pay less attention and provide less resource for this component and focus more on handling problems in quadrant I and III.

\section{Competitiveness of High School Graduates}

TABLE IV. COMPETITIVENESS OF HIGH SCHOOL GRADUATES IN WEST SUMBAWA, INDONESIA

\begin{tabular}{|c|c|c|c|}
\hline $\begin{array}{c}\text { Supporting } \\
\text { Factor }\end{array}$ & Score & Criteria & Description \\
\hline Input factor & 3.49 & Hesitate & $\begin{array}{l}\text { Tentatively materials and } \\
\text { learning programs in } \\
\text { schools, are still not in line } \\
\text { with the potential of local } \\
\text { advantages in KSB. }\end{array}$ \\
\hline $\begin{array}{l}\text { Demand } \\
\text { conditions }\end{array}$ & 2.64 & Hesitate & $\begin{array}{l}\text { The Competence of high } \\
\text { school graduates cannot } \\
\text { meet the expectations of } \\
\text { the business / industrial } \\
\text { world as well as the local } \\
\text { advantages, so the demand } \\
\text { for graduates is low. }\end{array}$ \\
\hline $\begin{array}{l}\text { Relevance of } \\
\text { Education with } \\
\text { the Industri } \\
\text { world }\end{array}$ & 3.41 & Hesitate & $\begin{array}{l}\text { SMA at KSB has the } \\
\text { diversity and uniqueness in } \\
\text { its development pattern, } \\
\text { but the majority of study } \\
\text { programs do not have any } \\
\text { compatibility with local } \\
\text { potential. }\end{array}$ \\
\hline $\begin{array}{l}\text { Education } \\
\text { Strategy }\end{array}$ & 2.94 & Hesitate & $\begin{array}{l}\text { In the context of regional } \\
\text { development of local and } \\
\text { regional seed sector, most } \\
\text { of the development pattern } \\
\text { of schools, courses and } \\
\text { competence are still } \\
\text { relatively less appropriate. }\end{array}$ \\
\hline
\end{tabular}

Overall

3.027 Hesitate

To produce graduates who are competent and competitive in KSB, then the four factors as recommended by Porter (1990), namely: input factors, demand conditions, the relevance of education to the world of industry and education strategy are needed. Table 4 visualize the research findings on the conformity of the criteria, namely: $<1.5$ abominable; $\geq 1.5$ and $<2.5$ bad; $\geq 2.5$ and $<3.5$ hesitate; $\geq 3,5$, and $<4.5$ is good, and $\geq$ 4.5 excellent.

\section{DISCUSSION}

How the Government of Indonesia see the quality of education can be affected by factors of context, input and 
process. Neither the context, input, and the actual process is reflected in the $8 \mathrm{NES}$ as stipulated in the Government Regulation No. 32 of 2013 on the Amendment of Indonesia Government Regulation No. 19 of 2005 on National Education Standards (Kemdikbud, 2013). The policy is in line with the results of the study of Seng and Ling (2013) which stressed the importance of educational institutions to have quality standards.

Nevertheless, the results of this study indicate unaccomplished content standards, processes, management, financing, facilities and infrastructure, as well as the competence of graduates based on the perception of stakeholders. This result seems to be different from the situation in some countries such as Slovenia, Croatia, and Hungary as indicated in the findings of Štimac and Šimić (2012), and also in Malaysia as clearly described in the findings of Seng and Ling (2013), although for different aspects and different levels of education. The study results Stimac and Šimić (2012) for example, found that the educational institutions in the area has good potential for market competition, as the criteria for management standards, educators, learning resources/infrastructure, cooperation between similar institutions, and others are all excellently met.

Research conducted by Palli and Mamilla (2012) also ensures a good level of service quality in the aspect of assurance, reliability, tangibility and empathy in India, though it is still weak in the aspects of responsiveness. The failure in accomplishing the quality standard in KSB was allegedly caused by the weakness of the competence and commitment of teachers and principals; less socialized policy, less coordination among stakeholders, less supervision from relevant educational institutions; and less partnerships and synergistic cooperation with higher education institution (PT). In addition, the target to have all students $(100 \%)$ pas the national exam leads to not optimized teaching and learning process.

This study also confirms the findings of local study in Indonesia which shows that the quality of educational services at the secondary level is still not satisfactory (Wildan et al., 2011; Muchlis et al., 2011). In addition to quality service, graduate competitiveness should also be a concern. Porter $(1990 ; 1998)$ states that there are four factors supporting the increase of competitiveness of graduates ie input factors, demand conditions, related and supporting industries, and strategy, structure and rivalry. In the context of education, the four factors are crucial in producing graduates who are competitive or have a competitive advantage.

Results of this study showed that all four of these factors has a weak supporting power. In the aspect of input, schools do not have conformity with local potential either due to the inconsistency in determining the quality of prospective learners or the development/establishment of schools is still not in accordance with the pattern of development of the area. In fact, input factors such as students, teachers, and others are considered to be the factors determining competitive advantage of school institutions. The study results of Ohmae (1994) also proves that the input may be a predictor factor for the achievement of the products (graduates) quality and competitiveness.
In addition to inputs, demand conditions also influence an institution (including educational institutions) to successfully achieve its objectives (Porter, 1990; 1998). Richardson et al. (1995) claim that when the content of study in an institution (school) aligns with the market (users), then the school will have a competitive advantage such as, the opportunities to do funding collaboration, scientific collaboration, and the like. The third determinant that determines the competitiveness of high school graduates is the relevance of education to Business World (DU)/ Working World (DK) / Industrial World (DI)/ local potential. Curran (1994) states that when a company (education) finds its relevance to the demands of the market, then the positive response of market as well as public participation will emerge in providing infrastructure, culture, skills, and other schools for competitive advantage. Finally, competitive strategy (education) also determines the competitiveness of graduates, because strategies can steer the institution, to detect possible risks, and further intervention/manipulation of demand conditions. Institutions that have a strong strategy are capable of facing the pressures and challenges. Porter (1998) states that the institution which has a competitive strategy will gain a competitive advantage, including educational institution.

The four aspects mentioned above determine the ability of educational institutions to produce graduates who are competitive and successful. The four components form a dynamic system that complements each other. The process of producing competitive graduates is highly dependent on the conditions of each of these components. Thus it can be understood that in order to produce competitive graduates, the four factors as noted by Porter (1998) must be met by secondary level educational institutions (high school) in KSB and in general in Indonesia.

Several limitations of this study include: (1) the study area is within the scope of the three districts in KSB so the results can not necessarily be generalized to other regions in Indonesia. Nevertheless, the results of some previous studies in other areas are in line with these findings; (2) the questionnaire is developed based on the itmes of every aspect of NES applied in Indonesia so that it differs from the quality of service aspects and instruments, as described by Parasuraman et al. (1991). Therefore, a more in-depth study, both in the study area as well as aspects of the study is needed.

\section{ACKNOWLEDGEMENTS}

Thanks go to: Government of West Sumbawa, Indonesia for providing facilities and financial support for the study: University of Mataram on the support of infrastructure; Directorate General of Higher Education, the Ministry of Research, Technology and Higher Education) for the financial support; and UPI for the opportunity presents the results of this study.

\section{REFERENCES}

[1] Amin, A. S. (2011). Peta dan strategi pendidikan menengah di Jawa Barat. Jakarta: Direktorat Jenderal Pendidikan Menengah Kementerian Pendidikan Nasional. 
[2] Badan Pusat Statisik/BPS Indonesia. (2013). Angka partisipasi sekolah (APS) menurut provinsi tahun 2003-2013. (Online), (http://www.bps.go.id/linkTabelStatis/ view/id/1527), diakses 2 Januari 2015.

[3] Badan Pusat Statisik/BPS Indonesia. (2014). Pengangguran terbuka menurut pendidikan tertinggi yang ditamatkan 20042014*. (Online), (http://www.bps.go.id/ linkTabelStatis/view/id/972), diakses 2 Januari 2015.

[4] Curran, P. J. (1994). The slope of the playing field. Area, 26, 249260.

[5] Dursun, T., Oskaybas, K., \& Gokman, C. (2014). Perceived quality of distance education the user perspective. Contemporary Educational Technology, 5, (2), 121-145.

[6] Kementerian Pendidikan dan Kebudayaan/Kemdikbud Indonesia. 2013. Peraturan pemerintah nomor 32 tahun 2013 tentang perubahan atas peraturan pemerintah nomor 19 tahun 2005 tentang standar nasional pendidikan. Jakarta: Kemdikbud.

[7] Martilla, J. A. \& James, J. C. (1977). Importance-performance analysis. Journal of Marketing, 41, (1), 77-79.

[8] Muchlis, Burhanuddin, Sukardi, Sutrio, Ismail, M., \& Taufik, M. (2011). Pemetaan kompetensi peserta didik dan pengembangan mutu pendidikan sekolah menengah atas di wilayah Propinsi Nusa Tenggara Barat (Laporan Penelitian). Mataram: Lembaga Penelitian Universitas Mataram.

[9] Nunnally, J. C. (1978). Psychometric theory (2end ed.). New York, NY: McGraw, Hill.

[10] Ohmae, K. (1990). The borderless world: Power and strategy in the interlinked economy. London: Harper Business.

[11] Palli, J. G. \& Mamilla, R. (2012). Students' opinions of service quality in the field of higher education. Creative Education, 3, (4), 430-438.

[12] Parasuraman, A., Zeithaml, V. A., \& Berry, L.L. (1985). A conceptual model of service quality and its implications for future research. Journal of Marketing, 49, 41-50.

[13] Parasuraman, A., Zeithaml, V. A., \& Berry, L.L. (1991). Marketing services: Competing through quality. New York: Macmillan.

[14] Parasuraman, A., Zeithaml, V. A., \& Berry, L.L. (1994). Reassessment of expectations as a comparison standard in measuring service quality: Implications for future research. Journal of Marketing, 58, 111-24.

[15] Porter, M. E. (1998). The competitive advantage of nations (with a new introduction by the author). Basingstoke: Macmillan.

[16] Porter, M. E. (1990). The competitive advantage of nations. New York: Free Press.

[17] Richardson, S., Nwanko, S. \& Richardson, B. (1995). Strategic issues for higher education strategists in the UK: A political contingency perspective. International Journal of Public Sector Management, 8, 7-16.

[18] Sallis, E. (1993). Total quality management in education. London: Kogan Page Educational Series.

[19] Seng, E. L. K. \& Ling, T. P. (2013). A statistical analysis of education service quality dimensions on business scholl students' satisfaction. International Education Studies, 6, (8), 136-146.

[20] Štimac, H. \& Šimić, M. L. (2012). Competitiveness in higher education: A need for marketing orientation and service quality. Economics \& Sociology, 5, (2), 23-34.

[21] Wildan, Sukardi, \& Musaddat, S. (2011). Naskah kajian strategi perencanaan pendidikan menengah di Nusa Tenggara Barat. Jakarta: Direktorat Jenderal Pendidikan Menengah Kementerian Pendidikan Nasional. 